\title{
SENGKETA KEWENANGAN PENGADILAN DALAM PERKARA WARIS AKIBAT ADANYA PILIHAN HUKUM
}

\author{
Eka Susylawati
}

(Jurusan Syari ah STAIN Pamekasan dan Alumni S2 Universitas Narotama Surabaya)

\begin{abstract}
Abstrak
Hukum waris sebagai bagian dari hukum perdata, memberikan kebebasan kepada pihak-pihak yang bersengketa untuk memilih hukum waris apakah yang dirasa cocok dan adil. Salah satu aturan yang mengatur perihal pilihan hukum dalam bidang hukum waris adalah Penjelasan Umum Undang-Undang Nomor 7 Tahun 1989, yang menyatakan bahwa pihak-pihak sebelum berperkara dapat mempertimbangkan untuk memilih hukum apa yang akan dipergunakan, apakah hukum waris Islam, adat atau Barat. Persoalannya, hukum waris Islam menurut Undang-Undang tersebut menjadi kewenangan pengadilan agama, dan hukum waris adat/Barat menjadi kewenangan pengadilan negeri. Sengketa kewenangan dapat terjadi jika dalam suatu sengketa waris terdapat pihak yang memilih hukum waris Islam dan sebagian yang lain memilih hukum waris adat/ Barat.
\end{abstract}

Kata Kunci:

waris, pengadilan, dan pilihan hukum

\section{Pendahuluan}

Di Indonesia bidang hukum waris merupakan salah satu bidang yang cukup menarik untuk dibicarakan, baik dari golongan masyarakat awam ataupun golongan intelektual. Hal ini wajar karena didalam masyarakat masih berlaku pluralisme $^{1}$ hukum, di mana tiga

1 Pluralisme hukum sering disebut juga dengan keanekaragaman hukum. Keanekaragaman hukum perdata tersebut merupakan realita bahwa negara Indonesia terdiri dari berbagai suku bangsa, agama dan adat istiadat. Perbedaan itu tercermin dalam tata hukum Indonesia yang keberadaannya masih disokong oleh 


\section{Eka Susylawati}

sistem hukum berlaku secara berdampingan yakni hukum waris Barat (BW), hukum waris adat dan hukum waris Islam.

Hukum waris Barat (BW) dianut oleh sebagian kecil masyarakat Indonesia, khususnya diterapkan oleh warga negara keturunan Eropa dan Timur Asing Thionghoa. Di lain pihak hukum waris adat dianut oleh sebagian besar masyarakat Indonesia sesuai dengan hukum adat masing-masing daerah. Sedangkan hukum waris Islam dianut dan diterapkan oleh masyarakat yang beragama Islam.

Pewarisan adalah masalah perpindahan harta, bahwa dengan meninggalnya seseorang maka hartanya terlepas dari dirinya dan berpindah menjadi hak milik ahli warisnya. ${ }^{2}$ Perpindahan harta itu sendiri pada umumnya dilakukan dengan cara pembagian. Hal ini biasanya terjadi karena ahli waris pada umumnya lebih dari seorang. Akibat yang mungkin timbul akibat pembagian waris tersebut adalah adanya sengketa sebagai ungkapan rasa tidak puas atas bagian yang harus diterimanya. Keadaan tersebut harus segera diatasi karena dapat menimbulkan perpecahan di antara ahli waris, padahal di antara ahli waris masih dalam ikatan hubungan darah atau masih dalam kerabat dekat.

Sebelum berlakunya Undang-Undang Nomor 7 Tahun 1989 tentang Peradilan Agama, khususnya di Jawa dan Madura, hanya pengadilan negeri yang mempunyai kewenangan menerima dan memutus sengketa waris. Dan pengadilan negeri dalam memeriksa dan memutus perkara waris tersebut mendasarkan kepada hukum adat atau hukum Barat. Sedangkan pengadilan agama pada saat itu hanya berwenang memberikan fatwa waris yang diajukan pihak-

hukum adat, hukum Islam dan hukum Barat. Hal ini dapat kita lihat dari norma dasar dalam Pasal II Aturan Peralihan Undang-Undang Dasar 1945, yang merupakan kelanjutan dari politik hukum Pemerintah Hindia Belanda. Lihat Afdol dan Lilik Kamilah, "Pola Pembagian Waris Berdasarkan Permohonan di Pengadilan Agama Surabaya dan Malang", Yuridika, Volume 14, (Januari - Pebruari 1999), hlm. 45.

2 Bandingkan dengan pengertian pewarisan menurut hukum adat. Dalam hukum adat proses pewarisan dapat dilakukan semasa pewaris masih hidup, yakni dengan jalan hibah dari orang tua kepada anaknya. Harta yang diperoleh melalui hibah tersebut nantinya ketika pewaris meninggal dunia akan diperhitungkan sebagai warisan. Lihat Hilman Hadikusuma, Hukum Waris Adat (Bandung: Alumni, 1980), hlm. 105. 


\section{Sengketa Kewenangan Pengadilan dalam Perkara Waris Akibat Adanya Pilihan Hukum}

pihak. Fatwa waris dari pengadilan agama tersebut tidak mempunyai kekuatan hukum yang mengikat. ${ }^{3}$

Pada umunya jarang dapat diketemukan bukti-bukti yang dapat menunjukan bahwa hukum waris Islam benar-benar diikuti oleh seorang yang beragama Islam ataupun orang non Islam yang menggunakan hukum waris adat atau Barat dengan seutuhnya. Hal ini disebabkan demikian beragamnya sistem hukum waris yang berlaku di masyarakat. Akibat dari keadaan di atas terdapat kemungkinan dalam satu sengketa waris ada pihak yang menundukan diri pada suatu hukum waris Islam, yang menjadi kewenangan dari pengadilan agama. Sedangkan pihak yang lain menyatakan tunduk pada hukum waris adat atau barat yang menjadi kewenangan dari pengadilan negeri.

\section{Kewenangan Pengadilan dalam Bidang Waris}

Sebelum membahas tentang kewenangan pengadilan agama dalam menyelesaikan perkara waris, terlebih dahulu akan diuraikan tentang kewenangan dari pengadilan negeri. Pengadilan negeri adalah lembaga perdilan yang berwenang menerima, memeriksa dan memutus perkara rakyat pada umumnya. Dikatakan umum karena kewenangan pengadilan negeri meliputi perkara perdata maupun pidana dari masyarakat secara umum.

Karena sifat umum itulah maka pengadilan negeri juga berwenang memeriksa dan memutus perkara waris yang diajukan oleh masyarakat. Namun yang membedakannya dengan pengadilan agama, pengadilan negeri dalam menyelesaikan perkara waris mendasarkan pada hukum adat dan Barat.

Dibandingkan dengan pengadilan negeri, sejarah atau proses pembentukan pengadilan agama teramat rumit dan panjang. Dan jika kita membicarakan kewenangan pengadilan agama dalam bidang waris di Indonesia tidak dapat dilepaskan dengan keadaan politik dan sejarah yang melatarbelakanginya.

Semula kedatangan bangsa Belanda yang bertujuan berdagang ke Indonesia, tidak mempengaruhi keberadaan hukum Islam yang

\footnotetext{
${ }^{3}$ Amir Syarifuddin, Hukum Kewarisan Islam (Jakarta: Prenada Media, 2005), hlm. 325.
} 


\section{Eka Susylawati}

telah ada. Malahan pada tahun 1855 dibentuk pengadilan agama yang berwenang menangani masalah perkawinan, waris dan wakaf. Namun setelah VOC digantikan dengan pemerintah penjajah yang sebenarnya, pemerintah belanda menganggap ajaran agama Islam sebagai penghalang dalam menjalankan politik hukumnya. Pada tahun 1937 dikeluarkanlah Staatsblad 1937-116 yang mengubah beberapa ketentuan yang ada di dalam Staatblad 1882-152.4

Setelah Indonesia merdeka tanggal 17 Agustus 1945, hal yang berkenaan dengan kewenangan pengadilan agama tidak banyak mengalami perubahan. Bila dibandingkan dengan kewenangan Mahkamah Syariah di luar Jawa dan Madura adalah lebih luas dibandingkan dengan kewenangan pengadilan agama di Jawa dan Madura. Hal tersebut dapat kita lihat dari isi pasal 4 ayat 1 Peraturan Pemerintah Nomor 45 Tahun 1957, yang mengatur tentang pembentukan Mahkamah Syariah di luar Jawa dan Madura.

Mahkamah Syariah memeriksa dan memutus perselisihan antara suami isteri yang beragama Islam dan segala perkara yang menurut hukum yang hidup diputus menurut hukum Islam, yang berkenaan dengan nikah, talaq, ruju', fasach, nafakah, mas kawin (mahar), mut'ah, hibah, sadaqah, baitul mal dan lain-lain yang berhubungan dengan itu, demikian juga memutuskan perkara perceraian dan mengesahkan bahwa syarat ta'lik sudah berlaku. ${ }^{5}$

Walaupun pengadilan agama khususnya di Jawa dan Madura sejak tahun 1937 secara formal sudah tidak berwenang lagi menerima perkara waris yang diajukan oleh pihak-pihak, tetapi pengadilan agama diperkenankan memberikan fatwa waris. Secara hukum, fatwa waris dari pengadilan agama tidak mempunyai kekuatan hukum yang mengikat, artinya meskipun dalam suatu perkara waris sudah dimintakan fatwa kepada pengadilan agama, namun pihak-pihak dapat memperkarakan kembali ke pengadilan negeri.

Kewenangan pengadilan agama mulai berubah sejak diundangkannya Undang-Undang Nomor 7 Tahun 1989 yaitu Undang-Undang Peradilan Agama, yang salah satu tujuannya agar terdapat kesatuan hukum dalam rangka hukum nasional, baik dalam

\footnotetext{
4 Ibid. hlm. 324.

5 Abdul Mutholib, Hand Out Hukum Waris Islam Fakultas Hukum Universitas Airlangga Surabaya (Surabaya: tp, 1991), hlm. 2.
} 


\section{Sengketa Kewenangan Pengadilan dalam Perkara Waris Akibat Adanya Pilihan Hukum}

peraturan hukum yang mendasarinya maupun dalam hal kewenangan. Dalam pasal 49 undang-undang tersebut secara tegas diatur mengenai kewenangan pengadilan agama yaitu bertugas dan berwenang memeriksa, memutus dan menyelesaikan perkara-perkara pada tingkat pertama antara orang-orang yang beragama Islam di bidang: 6

a. Perkawinan

b. Kewarisan, wasiat dan hibah yang dilakukan berdasarkan hukum Islam

c. Wakaf dan sadaqah.

Dengan Undang-Undang Nomor 7 Tahun 1989, khusus masalah waris, pengadilan agama berwenang memeriksa dan memutus perkara waris yang mempunyai kekuatan hukum mengikat seperti halnya putusan pengadilan negeri, dan tidak lagi hanya sebatas fatwa waris. ${ }^{7}$

\section{Sengketa Kewenangan Sebagai Akibat Adanya Pilihan Hukum}

Sebagaimana telah diuraikan sebelumnya, bahwa di Indonesia dalam hukum perdata saat ini masih terdapat keanekaragaman, di mana secara garis besar adat 3 (tiga) sistem hukum perdata yang berlaku yaitu hukum Islam, hukum adat dan hukum perdata barat. Ketiga hukum perdata di atas berlaku secara berdampingan dalam masyarakat.

Mengingat sedemikian beragamnya, maka terkadang sulit melihat seseorang untuk dikatakan tunduk pada hukum perdata tertentu. Misalnya saja seorang yang beragama Islam mungkin tunduk pada hukum adat atau seorang Indonesia asli (adat) menundukan diri pada hukum perdata barat (BW). Hal ini wajar

\footnotetext{
${ }^{6}$ Abdul Manan dan M Fauzan, Pokok-Pokok Hukum Perdata, Wewenang Peradilan Agama (Jakarta: PT Raja Grafindo Persada, 2002), hlm. 219.

7 Dengan adanya Undang-Undang Peradilan Agama yang memberikan kewenangan untuk memutus perkara waris maka hukum waris Islam merupakan hukum positif di Indonesia, khususnya bagi umat Islam. Sedangkan yang disebut dengan hukum positif adalah hukum yang berlaku dan dilaksanakan oleh negara melalui lembaga peradilan yang dibentuk oleh negara. Kedudukan Undang-Undang tersebut diperkuat posisinya dengan diberlakukannya Kompilasi Hukum Islam, yang disebarluaskan melalui Instruksi Presiden Nomor 1 Tahun 1991.
} 


\section{Eka Susylawati}

karena dalam hukum perdata ${ }^{8}$ terdapat asas yang menyatakan bahwa pihak-pihak bebas menentukan untuk tunduk pada hukum perdata tertentu sesuai dengan keyakinannya akan hukum yang paling cocok dengan dirinya.

Sebenarnya dalam pasal 49 ayat 1 b Undang-Undang Nomor 7 Tahun 1989 telah dinyatakan secara tegas bahwa masalah waris antara orang yang beragama Islam merupakan wewenang dari pengadilan agama. Namun isi pasal tersebut sepintas lalu bertolak belakang dengan Penjelasan Umumnya yang menyatakan bahwa pihak-pihak sebelum berperkara dapat mempertimbangkan untuk memilih hukum apa yang akan dipergunakan dalam pembagian warisan. ${ }^{9}$ Dari pemakaian istilah dapat, dapat ditarik kesimpulan bahwa para pihak boleh melakukan pilihan hukum, yakni hukum waris Islam, adat dan hukum waris barat. Dengan demikian pilihan hukum dapat diartikan sebagai kehendak para pihak untuk memilih hukum apa yang akan dijadikan hukum pemutus bagi perkara yang akan mereka ajukan. Dari isi Penjelasan Umum tersebut nampak sekali bahwa pilihan hukum harus terjadi di luar badan peradilan sehingga apabila tidak tercapai suatu kesepakatan, selama pihakpihak beragama Islam, maka seyogyanya perkara tersebut diperiksa dan diputus oleh pengadilan agama.

Dalam pasal 62 ayat 1 Undang-Undang Nomor 7 Tahun 1989 dinyatakan bahwa segala penetapan dan keputusan pengadilan selain harus memuat pasal-pasal tertentu dari peraturan-peraturan yang bersangkutan atau sumber hukum tak tertulis yang dijadikan dasar untuk mengadili. Yang dimaksud dengan hukum yang tidak tertulis yang dapat dijadikan dasar dalam pengambilan putusan, meliputi semua hukum yang hidup dan berlaku dalam masyarakat, misalnya hukum adat. Namun tidak semua hukum waris yang hidup dalam masyarakat bisa diterapkan di pengadilan agama karena hal tersebut akan bertentangan dengan pasal 49 ayat 3 di mana pengadilan agama dalam setiap pengambilan putusan dalam perkara waris senantiasa menerapkan hukum waris Islam.

${ }^{8}$ Menurut Van Apeldoorn, yang dikutip Wirjono Projodikuro dalam bukunya yang berjudul Asas-asas Hukum Perdata (Bandung: Sumur Bandung, 1983), hukum perdata diartikan sebagai peraturan-peraturan hukum yang mengatur kepentingan orang seorang dan pelaksanaanya terserah kepada yang berkepentingan

${ }_{9}^{9}$ Manan dan Fauzan, Pokok-Pokok Hukum Perdata, hlm. 237. 


\section{Sengketa Kewenangan Pengadilan dalam Perkara Waris Akibat Adanya Pilihan Hukum}

Karenanya pengadilan agama dalam memberikan pertimbangan tidak menjadikan pasal pasal 62 ayat 1 sebagai satusatunya landasan yuridis, melainkan harus pula memperhatikan faktor-faktor non yuridis, misalnya faktor sosiologis, sehingga pengadilan agama tidak dapat menerima begitu saja perkara yang diajukan oleh para pihak apabila hukum yang dipilih selain hukum waris Islam, melainkan memilih hukum waris adat. Bila hal tersebut terjadi maka pengadilan agama dapat memberikan nasehat kepada para pihak bahwa apabila mereka menginginkan masalah warisnya diselesaikan menurut hukum adat maka sebaiknya perkara tersebut diajukan ke pengadilan negeri. Namun pengadilan agama dapat pula menyarankan bahwa apabila pihak-pihak sepakat membagi harta waris tersebut berdasarkan hukum adat, maka pengadilan agama dapat menyelesaikan perkara tersebut (misalnya ahli waris anak lakilaki dan anak perempuan mendapat bagian yang sama atas harta waris yakni 1 : 1) sesuai dengan hukum adat, hanya saja dalam putusan pengadilan agama nantinya tetap mendasarkan pada hukum waris Islam (merupakan hasil kesepakatan atau musyawarah).

Para pihak bebas menentukan bentuk dan macam penyelesaian terhadap perkara waris mereka. Dan hakim di pengadilan agama haruslah menghormati penyelesaian yang dipilih oleh para pihak. Misalnya seorang suami meninggal dunia dengan meninggalkan seorang anak laki-laki, seorang anak angkat dan seorang isteri. Menurut hukum Islam, anak angkat tidak berhak mewaris atas harta peninggalan orang tua angkatnya. Tetapi isteri pewaris dapat memohon majelis hakim agar anak angkat tersebut juga diberi bagian dari harta peninggalan itu. Pengadilan agama akan mengabulkan permohonan penetapan tersbut dengan syarat permohonan itu disetujui oleh ahli waris yang lain (ahli waris anak laki-laki). Sehingga kesepakatan (musyawarah) itulah yang dapat didasarkan pasal 62 ayat 1 Undang-Undang Nomor 7 Tahun 1989.

Untuk mengatur lebih lanjut, Mahkamah Agung mengeluarkan Surat Edaran Mahkamah Agung (SEMA) Nomor 2 Tahun 1990 Tentang Petunjuk Pelaksanaan Undang-Undang Nomor 7 Tahun 1989, yang dalam point 5 menyatakan bahwa perkara waris yang terjadi antara pihak-pihak yang beragama Islam, akan tetapi diajukan ke pengadilan negeri sebelum tanggal 1 Juli 1990 tetap diperiksa dan diputus oleh pengadilan dalam lingkungan peradilan 


\section{Eka Susylawati}

umum. ${ }^{10}$ Dari isi SEMA di atas dapat ditafsirkan bahwa setelah tanggal 1 Juli 1990, pengadilan negeri tidak lagi berwenang menerima dan memeriksa perkara waris yang diajukan, kecuali pihak-pihak sepakat memilih hukum waris adat atau barat (BW). Bila dalam suatu masalah waris diajukan ke pengadilan negeri dan tidak ada pihak yang menolak maka para pihak dianggap tunduk pada hukum waris adat atau waris adat (BW).

Yang menjadi pertanyaan saat ini adalah sudah effektifkah isi dari SEMA Nomor 2 Tahun 1990 itu dilaksanakan, khususnya oleh pengadilan negeri. Selama masih ada kesepakatan di antara ahli waris maka SEMA tersebut di atas berlaku secara effektif. Sebaliknya apabila pengadilan negeri masih menerima dan memeriksa perkara waris antara orang-orang yang beragama Islam (bila tidak ada kesepakatan dalam memilih hukum waris apa yang akan diterapkan) maka dapat dikatakan SEMA tersebut belum effektif dilaksanakan. Sebab dapat saja terjadi, pengadilan negeri masih menerima dan memeriksa perkara waris itu karena adanya asas umum yang ada dalam pasal 16 Undang-Undang Kekuasaan Kehakiman, yang menyatakan bahwa pengadilan tidak boleh menolak suatu perkara dengan dalih tidak ada hukum yang mengatur atau dengan dalih hukumnya kurang jelas. ${ }^{11}$

Dengan demikian dapat disimpulkan bahwa pengadilan negeri baru berwenang memeriksa dan memutus perkara waris antara orang-orang yang beragama Islam sepanjang telah terjadi kesepakatan antara pihak-pihak untuk menyelesaikan sengketa warisnya di pengadilan negeri. Sebagai ilustrasi adalah sebagai berikut: Pewaris (Islam) meninggalkan seorang anak laki-laki dan seorang anak perempuan (keduanya juga beragama Islam). Apabila tidak ada kesepakatan karena ahli waris laki-laki memilih pengadilan agama sedangkan ahli waris perempuan memilih pengadilan negeri, maka gugatan ahli waris akan diajukan ke pengadilan yang berbeda.

\footnotetext{
10 Ibid., hlm. 264.

11 Hakim adalah pejabat negara yang selalu dianggap tahu hukum (ius curia novit). Apabila hakim tidak menemukan hukum yang tertulis, maka ia wajib menggali, mngukuti dan memahami nilai-nilai hukum yang hidup dalam masyarakat (pasal 28 ayat 1 Undang-Undang Kekuasaan Kehakiman). Dan yang termasuk dalam nilai-nilai hukum yang hidup di dalam masyarakat termasuk agama, budaya dan sebagainya. Lihat M. Nasir, Hukum Acara Perdata (Jakarta: Djambatan, 2003), hlm. 12.
} 


\section{Sengketa Kewenangan Pengadilan dalam Perkara Waris Akibat Adanya Pilihan Hukum}

Apabila pengadilan negeri benar-benar melaksanakan isi dari SEMA di atas, maka gugatan ahli waris anak perempuan akan diperiksa di pengadilan negeri dan ahli waris anak laki-laki mengajukan eksepsi bahwa pengadilan negeri tidak berwenang, maka pengadilan negeri dalam putusan selanya, harus menyatakan bahwa perkara waris itu bukanlah kewenangannya melainkan merupakan kewenangan pengadilan agama.

Eksepsi12 tentang kewenangan absolut yang diajukan oleh ahli waris anak laki-laki itu merupakan salah satu ukuran bahwa tidak ada kesepakatan dalam pemilihan hukum sebelum perkara diajukan. Karena tidak ada kesepakatan maka perkara waris itu seharusnya menjadi kewenangan absolut dari pengadilan agama dengan mendasrkan pada pasal 49 ayat 1 b Undang-undang Nomor 7 Tahun 1989. Sebenarnya tanpa eksepsi absolutpun, hakim di pengadilan negeri harus menyatakan bahwa pengadilan negeri tidak berwenang mengadili sebab hakim wajib menyatakan hal tersebut apabila perkara itu bukan merupakan kewenangan absolut pengadilan negeri.

\section{Analisis dan Penyelesaian Masalah Pilihan Hukum}

Kenyataan dalam masyarakat bahwa pilihan hukum dapat menimbulkan benturan kewenangan antara pengadilan agama dan pengadilan negeri. Benturan kewenangan tersebut perlulah diberikan solusinya sebab bila hal tersebut dibiarkan maka akan menimbulkan kebingungan para pencari keadilan, yang pada akhirnya akan mengakibatkan ketidakpercayaan masyarakat akan lembaga-lembaga peradilan negara sehingga masyarakat akan mencari penyelesaian masalah warisnya dengan cara-caranya sendiri (di luar badan peradilan negara).

Sepintas lalu keadaan di atas terkesan menguntungkan pada para pihak sebab akan mempermudah penyelesaian sengketa. Penyelesaian di luar lembaga peradilan itu tidak akan menimbulkan masalah, apabila para pihak dengan itikat baik melaksanakan apa

\footnotetext{
12 Eksepsi disebut juga tangkisan perihal tidak berkuasanya hakim dan di dalam HIR hanya mengenal 2 macam yakni eksepsi yang menyangkut kekuasaan absolut dan eksepsi yang menyangkut kewenangan relatif. Kedua eksepsi tersebut menyangkut acara, yang dalam hukum acara perdata disebut eksepsi prosesual. Lihat Subekti, Hukum Acara Perdata (Jakarta: Binacipta, 1980), hlm.59.
} 


\section{Eka Susylawati}

yang telah disepakatinya. Sebaliknya, akan menimbulkan persoalan baru apabila pihak-pihak memperkarakan kembali masalah waris tersebut ke lembaga peradilan. Padahal mungkin harta warisnya sudah tidak dalam porsi sedia kala atau malahan sudah habis.

Salah satu cara menyelesaikan masalah yang timbul akibat pilihan hukum ini adalah dengan cara mengembalikan pada aturanaturan yang mengaturnya. Metode yang digunakan dengan melakukan interpretasi/penafsiran terhadap ketentuan-ketentuan yang terkait, khususnya yang ada hubungannya dengan pilihan hukum.

Ketentuan pertama yang harus dikaji adalah Penjelasan Umum angka 2 alinea ke-6 Undang-Undang Nomor 7 Tahun 1989 yakni ketentuan yang mengisyaratkan diperkenankannya pilihan hukum, di mana pihak-pihak dapat mempertimbangkan untuk memilih hukum apa yang akan dipergunakan di dalam pembagian warisan. Dari kata sebelum tersebut dapat disimpulkan bahwa kesepakatan itu di luar badan peradilan. Dengan demikian apabila perkara waris sudah masuk dalam pengadilan maka hak pilihan hukum sudah tidak berarti lagi. Jadi apabila pihak-pihak yang beragama Islam (yang sebenarnya masuk dalam kewenangan pengadilan agama) sebelum perkara diajukan ke pengadilan sepakat untuk memilih hukum waris adat atau barat yang menjadi kewenangan pengadilan negeri, maka kesepakatan pilihan hukum tersebut dituangkan dalam suatu pernyataan bersama dan ditandatangani oleh pihak-pihak serta dilampirkan bersama gugatannya ke pengadilan negeri. Sebenarnya pernyataan tertulis tersebut bukanlah suatu yang mutlak harus ada apabila perkara waris itu jatuh dalam lingkungan pengadilan negeri dan tidak ada pihak yang menolaknya, maka dapat dikatakan bahwa semua pihak menerima untuk menyelesaikan sengketa waris itu ke pengadilan negeri. Sebaliknya jika tidak tercapai kesepakatan, maka pengadilan negeri tidak berwewenang memeriksa da memutus perkara waris tersebut.

Di dalam praktik peradilan seringkali agama si pewarislah (orang yang meninggal dunia) yang dijadikan dasar untuk menentukan dengan cara bagaimanakah suatu harta peninggalan dibagi. Hal ini sudah menjadi prinsip hukum yang bersifat umum dan bahkan hal tersebut sudah menjadi yurisprudensi Mahkamah Agung. Dasar pemikirannya adalah bahwa pewarisan merupakan 


\section{Sengketa Kewenangan Pengadilan dalam Perkara Waris Akibat Adanya Pilihan Hukum}

fakta hukum, yang menimbulkan akibat hukum, artinya bahwa pewarisan adalah suatu yang mutlak berlaku sesuai dengan hukum yang dianut sehingga para pihak tidak dapat melakukan pilihan hukum. ${ }^{13}$

Pilihan hukum ada di luar peradilan mempunyai sisi positif bagi perkembangan hukum nasional, karena diharapkan nantinya pertentangan antara hukum waris adat dan hukum waris Islam seperti pada jaman Hindia Belanda berangsur-angsur dapat dihilangkan. Selain itu, hakim di pengadilan tidak akan terlibat di dalam perkara yang diajukan oleh pihak-pihak sebab bisa saja terjadi pihak-pihak yang berperkara tidak sepakat dalam memilih hukum dan hakim memutus hukum yang akan diterapkan pada putusan berlandaskan pada rasa subyektifitas dirinya sendiri.

Masalah benturan kewenangan itu akan lebih nampak lagi apabila ada pihak yang mengajukan perkara warisnya ke pengadilan negeri dan pengadilan negeri beranggapan berwenang mengadilinya. Hal ini dapat menimbulkan masalah sebab penentuan ahli waris menurut hukum Islam berbeda dengan hukum adat dan hukum Barat, maka tidak menutup kemungkinan untuk menggugat ke pengadilan negeri. Misalnya terdapat anak pewaris yang berbeda agama dengan orang tuanya sehingga menurut hukum Islam terhalang baginya untuk memperoleh warisan, padahal menurut hukum waris adat walaupun ada perbedaan agama seorang anak tetap mewaris dari orang tuanya. ${ }^{14}$ Anak yang berbeda agama tersebut ada masih dapat menggugat ahli waris yang lain ke pengadilan negeri.

Penafsiran lain yang dapat digunakan dalam menyelesaikan masalah pilihan hukum adalah bahwa ketentuan kewenangan pengadilan agama dalam bidang waris sebagaimana diatur dalam pasal 49 ayat $1 \mathrm{~b}$ merupakan aturan yang bersifat khusus, sedangkan Penjelasan Umum yang memungkinkannya dilakukan pilihan hukum adalah ketentuanyang bersifat umum. Dengan demikian jika terdapat pertentangan antara keduanya, maka ketentuan khususlah yang akan diberlakukan berdasarkan asas lex specialis derogat lex generalis.

\footnotetext{
13 Putusan Mahkamah Agung Nomor 172K/Sip./1974 tanggal 6 Maret 1975.

14 R. Soepomo, Bab-Bab tentang Hukum Adat (Jakarta: Pradnya Paramita, 2000), hlm. 85.
} 


\section{Eka Susylawati}

Akibatnya berdasarkan asas tersebut maka apabila dalam suatu sengketa waris tidak terdapat kesepakatan dalam menentukan pilihan hukum maka berdasarkan pasal 2 jo 49 ayat $1 \mathrm{~b}$, perkara waris itu tetap merupakan kewenangan pengadilan agama.

Asas hukum lex specialis derogat lex generalis di atas, diperkuat lagi dengan Surat Edaran Mahkamah Agung (SEMA) Nomor 2 Tahun 1990 yang menyatakan bahwa perkara waris yang terjadi antara pihak-pihak yang beragama Islam akan tetapi diajukan ke pengadilan negeri sebelum tanggal 1 Juli 1990 tetap diperiksa, diputus dan diselesaikan oleh pengadilan di lingkungan peradilan umum. Ketentuan ini dapat ditafsirkan secara a contrario ${ }^{15}$ bahwa sesudah tanggal 1 Juli 1990 perkara-perkara waris di mana pihak-pihaknya beragama Islam akan menjadi kewenangan pengadilan agama. Sehingga apabila tidak ada kesepakatan dalam memilih hukum karena sebagian ahli waris berkeinginan mengajukan ke pengadilan negeri, maka sebenarnya pengadilan negeri harus menyatakan tidak berwenang mengadili.

Penyelesaian masalah sengketa kewenangan mengadili, yang diselesaikan dengan melakukan penafsiran terhadap peraturan perundang-undangan yang terkait, adalah bersifat teoritis. Sedangkan dalam praktiknya di dalam masyarakat bisa saja menggunakan penafsiran lain, yang akan menghasilkan pemikiran yang berbeda, yang pada intinya mempertahankan pendapat bahwa pengadilan negeri tetap berwenang mengadili perkara waris walaupun tidak ada kesepakatan dalam pemilihan hukum.

\section{Peranan Mahkamah Agung dalam Menyelesaikan Sengketa Kewenangan}

Mahkamah Agung adalah lembaga pengadilan negara yang tertinggi dari semua lingkungan peradilan yang di dalam melaksanakan tugasnya terlepas dari pengaruh pemerintah. Dari isi pasal tersebut dapat disimpulkan bahwa kekuasaan kehakiman di semua lingkungan peradilan baik di lingkungan peradilan umum,

15 A contrario mempunyai makna kebalikannya, lawan dari suatu kata. Sehingga penafsiran a contrario adalah salah satu penafsiran di dalam hukum dengan jalan mencari kebalikan makna dari suatu pernyataan. 


\section{Sengketa Kewenangan Pengadilan dalam Perkara Waris Akibat Adanya Pilihan Hukum}

agama, militer dan peradilan tata usaha negara berpuncak pada Mahkamah Agung.

Peranan Mahkamah Agung dalam menyelesaikan sengketa yang timbul akibat adanya pilihan hukum sangat besar. Peranan Mahkamah Agung dalam hal ini terutama apabila baik pengadilan agama dan pengadilan negeri menyatakan bahwa keduanya berwenang.

Berdasarkan pasal 11 Undang-Undang Nomor 4 Tahun 2004, Mahkamah Agung mempunyai kewenangan untuk memutus pada tingkat pertama dan terakhir semua sengketa kewenangan mengadili antara dua pengadilan di lingkungan peradilan yang berbeda. Dengan demikian maka sengketa kewenangan mengadili itu haruslah diajukan ke Mahkamah Agung. Hal ini sangat penting untuk menghindari adanya dua putusan oleh dua lingkungan peradilan dalam satu perkara waris, dan tentu saja hal tersebut akan membingungkan para pencari keadilan.

Untuk melihat peranan Mahkamah Agung di dalam proses penyelesaian sengketa kewenangan, akan digambarkan dengan melalui kasus hipotesis, sebagai berikut :

Pewaris meninggal dunia dengan meninggalkan sorang anak laki-laki (A) dan seorang anak perempuan (B). Pewaris dan ahli waris kesemuanya beragama Islam. Kemudian A mengajukan gugatan ke pengadilan agama. Tetapi B tidak sependapat dengan A, sehingga B mengajukan gugatan atas A di pengadilan negeri dengan harapan misalnya pembagian harta waris tersebut didasarkan pada hukum waris adat.

Dari kasus hipotesis di atas terlihat bahwa pihak-pihak memilih hukum waris yang berbeda dan berakibat pada kewenangan lembaga peradilan yang berbeda pula.

Adapun akibat yuridisnya adalah:

-Pada awal persidangan, hakim menawarkan perdamaian dan jika tidak tercapai, sedangkan tergugat (B) tidak hadir pada persidangan maka pengadilan agama akan memutus verstek. ${ }^{16}$

\footnotetext{
16 Putusan verstek adalah putusan hakim dengan mengabulkan gugatan penggugat di luar hadir tergugat atau kuasanya setelah dipanggil secara patut. Dengan ketidakhadiran tersebut tergugat dianggap setuju terhadap apa yang akan diputuskan oleh hakim. Lihat Nasir, Hukum Acara, hlm. 111.
} 


\section{Eka Susylawati}

Terhadap putusan vertek ini, B dapat melakukan perlawanan dengan mengajukan verzet (pasal $129 \mathrm{HIR}$ ).

-Demikian juga pengadilan negeri akan mengabulkan gugatan $\mathrm{B}$ dengan putusan verstek terhadap A yang tidak hadir di persidangan. Sama halnya dengan proses di pengadilan agama, maka A dapat mengajukan perlawanan.

Penyelesaian kasus hipotesis di atas terjadi apabila pihak tergugat (A di pengadilan negeri dan B di pengadilan agama) tidak hadir dalam persidangan. Sedangkan apabila masing-masing pihak hadir, maka akibat yuridisnya adalah:

-A dapat mengajukan eksepsi dalam persidangan di pengadilan negeri bahwa pengadilan negeri tidak berwenang untuk mengadili perkara waris tersebut. Demikian juga B, dapat mengajukan eksepsi tentang hal yang sama di persidangan pengadilan agama. Eksepsi tentang kewenangan absolut ini dapat diajukan setiap waktu selama persidangan berlangsung.

-Terhadap eksepsi tentang kewenangan absolut, baik pengadilan agama dan pengadilan negeri akan memeriksanya. Bila eksepsi itu diterima, maka pengadilan akan menyatakan dirinya tidak berwenang mengadilinya. Sebaliknya, apabila eksepsi tersebut ditolak maka dijatuhkan putusan sela pengadilan negeri dan pengadilan agama kemungkinan besar akan cenderung memenangkan penggugat. Hal ini wajar sebab sistem hukum yang djadikan pertimbangan putusan berbeda, penggugat di pengadilan negeri berdasrkan pada hukum adat/Barat dan penggugat di pengadilan agama berdasarkan hukum Islam.

-Pihak yang kalah akan mengajukan banding, A mengajukan banding ke Pengadilan Tinggi dan B mengajukan bandingnya ke Pengadilan Tinggi Agama. Akhirnya seperti penyelesaian kasus hipotesis yang pertama, perkara tersebut akan diperiksa dan diputus oleh Mahkamah Agung.

Bila kita cermati dari dua kasus hipotesis di atas, nampak sekali bahwa masalah pilihan hukum tidak akan pernah selesai di pengadilan tingkat pertama atau tingkat banding, melainkan pada kasasi. Dalam hal tersebut tentunya Mahkamah Agung diharapkan memberikan putusan yang seadil-adilnya.

Cara penyelesaian masalah pilihan hukum melalui proses pada tingkat pertama dan tingkat banding sebagaimana di atas, 


\section{Sengketa Kewenangan Pengadilan dalam Perkara Waris Akibat Adanya Pilihan Hukum}

mengandung sisi positif. Kelebihannya adalah Mahkamah Agung akan secara kasuistis di dalam memutuskannya, sehingga putusan akan relatif lebih adil. Hal ini disebabkan Mahkamah Agung akan mempertimbangkan semua aspek, tidak hanya aspek yuridis tetapi juga aspek yang lain, misalnya aspek sosiologis. Sebagai contoh misalnya dalam suatu sengketa waris terdapat anak angkat (adoptie) ${ }^{17}$. Menurut hukum waris Islam, anak angkat tidak berhak mewaris atas harta peninggalan orang tua angkatnya. Namun Mahkamah Agung dapat memutuskan bahwa anak angkat tersebut juga akan mewaris. Bila itu terjadi maka Mahkamah Agung berarti memasukan unsur hukum waris adat di dalam putusan yang mendasarkan pada hukum waris Islam.

Apabila dibandingkan dari sisi positifnya, maka sisi negatifnya lebih besar. Sisi negatif apabila semua masalah pilihan hukum diajukan ke Mahkamah Agung untuk dimintakan kasasi, maka akan menambah beban perkara yang harus diselesaikan Mahkamah Agung, padahal setiap tahunnya perkara kasasi semakin menumpuk. Sedangkan jika ditinjau dari kepentingan pihak-pihak, maka proses penyelesaian melalui proses tingkat pertama dan banding, memerlukan waktu yang relatif lama dan biaya yang besar. Selain hal tersebut kita ketahui bahwa masalah waris adalah masalah yang harus dapat diselesaikan dalam waktu yang secepat mungkin sebab dikuatirkan harta peninggalan sudah tidak dalam porsi yang sesungguhnya karena disalahgunakan oleh pihak yang tidak beritikat baik.

17 Seringkali di masyarakat menyamakan istilah anak angkat dan adoptie, karena memang sepintas lalu memang sama yakni, mengangkat anak orang lain sebagai anak sendiri. Namun dari sisi hukum kedua istilah tersebut berbeda. Perbedaannya, jika anak angkat merupakan terminologi dari hukum adat, sedangkan adoptie berasal dari hukum barat (BW). Perbedaan lainnya, jika pada adoptie, seorang anak akan terputus hubungan perdata dengan orang tua kandungnya sehingga hanya akan mewaris dari orang tua yang mengadoptienya, sedangkan "anak angkat", khususnya pada masyarakat parental seperti yang berlaku di Jawa dan Madura, seorang anak angkat tidak terputus secara perdata dengan orang tua kandungnya sehingga seorang anak angkat dari mewaris dari 2 (dua) sumber yakni dari orang kandungnya dan orang tua angkatnya. Bandingkan pendapat Soeroyo Wigyodipoero dalam Pengantar Hukum Adat (Jakarta :Gunung Agung, 1982), hlm 54, dengan pendapat JCT Simongkir dalam Kamus Hukum (Jakarta: Sinar Grafika, 2000), hlm. 4 


\section{Eka Susylawati}

Berdasarkan fakta di atas, maka diperlukan adanya kesepakatan dalam pemilihan hukum, yang sebaiknya diselesaikan pada tingkat pertama. Apabila ada sengketa kewenangan mengadili baik di pengadilan negeri mapun di pengadilan agama sebagai pengadilan tingkat pertama mendeponir ${ }^{18}$ proses perkara tersebut dan mengajukannya ke Mahkamah Agung. Mahkamah Agung nantinya akan memutuskan pengadilan manakah yang berwenang mengadili perkara waris tersebut, tentu saja dengan mendasarkan pada perundang-udangan yang berlaku dan rasa keadilan yang hidup dalam masyarakat.

18 Istilah deponir, yang dapat diartikan menahan, dalam praktik lebih dikenal dalam hukum acara pidana yakni tidak dilanjutkannya (baca: sementara) suatu perkara ke pengadilan karena tidak cukup bukti. Misalnya penuntutan seorang terdakwa ke pengadilan oleh jaksa penuntut umum tidak dapat dilanjutkan karena alasan tidak cukup bukti. Sedangkan dalam hukum acara perdata deponir diartikan sebagai proses penghentian untuk sementara proses suatu perkara, karena suatu sebab yang dapat dibenarkan oleh Undang-Undang, misalnya karena adanya sengketa tentang kewenangan absolut. Setelah ada putusan dari Mahkamah Agung tentang pengadilan manakah yang berwenang, maka perkara tersebut dilanjutkan proses pemeriksaannya sampai pada putusan. 